\title{
Respiratory conditions: effect of housing and other factors
}

\author{
P McCARTHY, D B YRNE, S HARRISSON, AND J KEITHLEY \\ From the Health Care Research Unit, University of Durham, Department of Sociology and Social Policy
}

SUMMARY The public health movement has been concerned with the relation between housing and health for well over a century. Nevertheless the Black Report still identified housing as one of the major causes of ill-health and suggested, on one indicator at least, that council housing is the least healthy form of tenure. An exploratory study concerning housing and health in a north eastern local authority area is described. It was found that smoking, work experience, and age were the most important determinants of self assessed respiratory conditions. When the background factors were held constant people in areas of 'bad' housing were found to report more respiratory symptoms than those in 'good' housing areas. Respiratory conditions were affected by the age of housing, and flats were found to be worse than houses. High rise flats were worse than low or medium rise flats.

The public health movement has shown a traditional concern with the relation between the health of the population and the housing in which they live. In his historical analysis of health in 19th century Britain, Wohl' ${ }^{1}$ comments:

\begin{abstract}
"As the century progressed it became increasingly apparent that the growing structure of public health rested on domestic foundations and that the nation could not be healthy unless it housed its masses in healthy housing."
\end{abstract}

This concern with the effect of housing on health progressed into the 20th century. Before the second world war a plethora of research demonstrated a causal connection between the dwellings in which people live and their state of health. In particular, tuberculosis was shown to be closely connected with over crowding and lack of basic amenities. ${ }^{2}$ At the time the housing market was dominated by the privately rented sector: in $191490 \%$ of dwellings were rented from private landlords. Since then there has been a marked growth of public intervention in the housing market which, together with a large increase in owner occupation, reduced the privately rented sector to $12 \%$ of dwellings by $1982 .^{3}$

The development of public sector housing led to substantial improvement in the housing conditions enjoyed by most of the population. The 1981 census recorded the smallest ever proportion of households lacking all the basic amenities, and similarly low levels of overcrowding. This development has made a significant impact on the health of the population.
Consequently sociological interest in the relation between bad housing and ill health has declined. The Black Report on "Inequalities in Health" demonstrated the absence of recent research. It did, however, examine the relation between tenure and mortality rates and concluded that:

\footnotetext{
"People who live in houses which they own have lower rates of mortality than those who rent their homes from private landlords, who in turn have lower rates than those who are tenants of local authorities."4
}

More recently, Morgan and Chinn ${ }^{5}$ have shown that children who live in neighbourhoods classified as "urban local authority housing" are more likely than others to experience respiratory illness.

Given that the public sector has provided vastly improved housing for a large proportion of the population, it is surprising to find that, on some indicators, people who live in council housing are less healthy than those in alternative forms of tenure. This may be accounted for by the existence in the public sector stock of housing forms with almost no parallel in the private sector. Public sector housing is more heterogeneous in form than other forms of tenure. It includes dwelling types seldom found elsewhere-non-traditional, or system built, medium and high rise flats-as well as the semi detached and terrace houses and low rise flats which are essentially identical with the stock provided by market mechanism for owner occupation. ${ }^{6}$ 
The health effects of housing form have been illustrated by Fanning. ${ }^{7} \mathrm{He}$ compared houses and four-storey flats with equivalent social mixes and found that rates of general practitioner consultation were higher for flat dwellers of all age groups. Respiratory problems were the major reason for high consultancy rates among those who lived in flats.

The relation between housing and health is fairly complex. Ill health is associated with many factors, such as genetic pre disposition, age, sex, occupation, income, and consumption habits, some of which may co-vary with housing conditions. People who live in the poorest houses also tend to take up the least healthy employment, live in the worst environments, and consume the poorest diets. Respiratory disorders may be the combined outcome of working in a dirty atmosphere, breathing polluted inner city air, smoking, and living in a damp and draughty house.

An exploratory study was undertaken which aimed to identify the housing, health, and other relevant conditions of households located in a range of public sector dwellings, and to provide an explanation for the impact of housing on health, taking other relevant factors into account. The study included a survey among occupants of local authority accommodation in a metropolitan district located in the north-east of England. Information was collected regarding several facets of health and illness and included several items relating to respiratory conditions.

A total of 674 adults and 228 children, in 383 households, were interviewed. The data presented here refer to 533 adults below retirement age.

\section{Measurement}

Questions designed to elicit symptoms of respiratory conditions were adapted from a Medical Research Council standard questionnaire. The items used were:

Do you become breathless or have any pain or fits of coughing when you hurry?

Do you usually cough first thing in the morning (excluding single cough or clearing throat)?

Do you usually cough during the day or at night (excluding single cough or clearing throat)?

Does your chest ever sound wheezy or whistling?

Do colds usually go to your chest?

If yes to any:

Do you get this/these on most days or nights?

Responses to the symptom questions were used to construct cumulative indices of respiratory conditions. A score of one was assigned to each positive response. All items were then added together, divided by six, and multiplied by ten. This results in a scale ranging from 0 to 10 with high scores associated with high degrees of respiratory disorder.
Thus the severity of respiratory problems is assumed to be a factor of the number of symptoms present.

The reliability of the derived scale was estimated using Cronbach's Alpha, a measure of internal consistency. ${ }^{8}$ The coefficient was 0.792 .

Assessing the validity of a scale is a more complex problem than measuring reliability. One way of tackling the problem is to relate scales to other measures which measure incidence of respiratory problems. This relates to construct validity which:

"focuses on the assessment of whether a particular measure relates to other measures consistent with theoretically derived hypotheses concerning the concepts (or constructs) that are measured.",9

We need to know whether the scale of respiratory conditions is positively associated with other means $\vec{A}$ of detecting the presence of respiratory disorders. Respondents were asked whether they suffered from long standing illness or had been ill during the previous two weeks and, if so, the nature of the illness. If the respiratory conditions scale is valid, there should be an association between scale scores and the propensity to report respiratory conditions as types of illness. Point bi-serial correlations ${ }^{10}$ wer $\vec{\oplus}$ 0.41 for respiratory conditions relating to lon standing illness and 0.25 for those relating to illnes during the last two weeks. In addition, respondent were asked whether they had ever suffered frono bronchitis, pneumonia, or pleurisy. Point bi-seria correlations were $0.47,0.27$, and 0.29 respectively These correlations are not large, but all are in the of correct direction and significant beyond the 0.0001 level, which suggests that the scale has some validity.

\section{Analysis}

Analysis of variance was conducted with five $\overrightarrow{\vec{P}}$ independent variables.

These were:

Housing area-classified into "good" and "bad" ? housing areas. Bad areas are those estates which have been defined by the local authority as "difficult-to-let".

Dwelling type-houses, low to medium rise flats, high rise flats (above 8 storeys).

Smoking-smoker, ex-smoker, passive smoker, non-smoker (ie, no member of the household smokes).

Worked in unhealthy environmentrespondents were asked whether they had ever worked in an environment which they $\mathcal{N}$ considered to be bad for health. Responses were $N$ either "yes" or "no".

Household class-several studies have suggested a relation between social class and health. 
Several of these were used as evidence in the Black Report which demonstrated consistently that members of the lower social classes suffer inferior standards of health compared with members of the upper social strata. For instance, a study of the prevalence of chronic bronchitis among patients aged 40 to 64 registered with 91 general practitioners showed that:

"In terms of GP diagnosis, the percentage suffering from chronic bronchitis rose with descending class from $6 \%$ in class I to $26 \%$ in class V."11

The location of a household in the housing market is, to a large extent, dependent on its location in the class structure. The households selected for this study share a common location in a specific housing tenure, a type of tenure designed for working class consumption. Therefore there is little variation when households are classified according to traditional definitions. In these circumstances, indicators that reflect levels of working class unemployment and dependence on state financial benefits have potentially greater substantive value. Verbrugge ${ }^{12}$ has suggested that currently employed people are much healthier than others, tending to have lower rates of acute illness, chronic conditions, and restricted activity, and have fewer symptoms of ill health. However, we have treated income dependency as a characteristic of households rather than of individuals. Thus individual members of households are judged to share common class situations based on dependency on state benefits. The derived classification has five categories (items 1 and 2 are not relevant here):

1 Households containing only pensioners, with no income other than state pension.

2 Other households which contain only pensioners.

3 Non-pensioner households with no income other than state benefit.

4 Non-pensioner households receiving some state benefits other than child benefits, but also having some alternative sources of income.

5 Non-pensioner households not receiving state benefits other than child benefit.

The initial stage of analysis of variance is a two-way analysis with housing area and housing type as independent variables. This examines whether respiratory conditions are related to housing location or to housing form. Conventional methods of analysis of variance, which assume orthogonality, are inappropriate because of unequal and disproportionate sub class frequencies. In this kind of situation, main effects tend to be entangled with one another and with interaction. Thus the method of fitted constants, ${ }^{13}$ an adaptation of analysis of variance, was used. Prior analysis of variance had revealed non-significant interaction $(p=0 \cdot 424)$.

Constants are thus fitted to the model:

$$
Y i j k=\mu+a i+b j+e i j k
$$

The results of the corresponding tests of significance are shown in table 1 . These suggest that housing area and housing type each have a significant effect on respiratory conditions. Thus when housing area is held constant housing type still has a significant effect.

Table 1 Fitted constants-housing area by housing type

\begin{tabular}{lrcrc}
\hline & $\begin{array}{c}\text { Sum of } \\
\text { squares }\end{array}$ & $\begin{array}{c}\text { Degrees of } \\
\text { freedom }\end{array}$ & $F$ & $\begin{array}{c}\text { Significance } \\
\text { of } F\end{array}$ \\
\hline Within cells (i,k) & 5058 & 525 & & \\
Constant (u) & 3162 & 1 & 328.2 & 0.0 \\
Housing area & 101 & 1 & 10.5 & 0.001 \\
Housing type & 59 & 2 & 3.1 & 0.048 \\
\hline
\end{tabular}

This analysis was extended to include five independent variables: housing area, housing type, household class, smoking, and whether worked in an unhealthy environment. In addition, age was included as a co-variate. Analysis of co-variance reveals significant association relating to the co-variate and the combined main effects. First order interaction is non-significant $(p=0 \cdot 13)$. Higher order interaction effects cannot be calculated due to the presence of empty cells.

Table 2 gives the results of tests of significance for the five-way model for fitted constants for the main effects. These indicate significant effects for smoking, housing area, and having worked in an unhealthy environment. When the other independent variables and the co-variate are taken into consideration household class and housing type do not have a significant effect on respiratory conditions.

Multiple classification analysis, shown in table 3, breaks down effects into individual components. This shows that the model explains $20.8 \%$ of the variance in respiratory conditions. Smoking is the most important effect. The worst respiratory conditions are experienced by those who currently smoke; next

Table 2 Fitted constants-analysis of co-variance

\begin{tabular}{lrrrr}
\hline & $\begin{array}{c}\text { Sum of } \\
\text { squares }\end{array}$ & df & \multicolumn{1}{c}{$F$} & $\begin{array}{c}\text { Significance } \\
\text { of } F\end{array}$ \\
\hline Within cells & 3138 & 395 & & \\
Regression & 58 & 1 & 7.4 & 0.007 \\
Constant & 116 & 1 & 14.6 & 0.000 \\
Household class & 13 & 2 & 0.8 & 0.454 \\
Smoking & 373 & 3 & 15.7 & 0.000 \\
Housing type & 18 & 2 & 1.1 & 0.331 \\
Housing area & 52 & 1 & 6.5 & 0.011 \\
Worked in & 190 & 1 & 23.9 & 0.000 \\
$\quad$ unhealthy environment & & & & \\
\hline
\end{tabular}


come ex-smokers, then passive smokers, and the lowest levels of respiratory conditions are found among respondents who do not smoke and who live in non-smoking households. Respondents who have worked in unhealthy environments suffer worse respiratory conditions than those who have not. Respiratory conditions are more acute among residents in "bad" housing areas than among their counterparts in "good" housing.

Table 3 Multiple classification analysis

\begin{tabular}{|c|c|c|c|c|c|}
\hline & & $\begin{array}{l}\text { Deviations from } \\
\text { mean-unadjusted }\end{array}$ & eta & $\begin{array}{l}\text { Deviations. from } \\
\text { mean-adjusted } \\
\text { for independent } \\
\text { and co-variates }\end{array}$ & beta \\
\hline $\begin{array}{l}\text { Household } \\
\text { class }\end{array}$ & $\begin{array}{c}\text { Social Security } \\
\text { dependent } \\
\text { Low income } \\
\text { Independent }\end{array}$ & $\begin{array}{r}0.28 \\
0.40 \\
-0.47\end{array}$ & $0 \cdot 13$ & $\begin{array}{r}-0.14 \\
0.26 \\
-0.05\end{array}$ & 0.05 \\
\hline Smoking & $\begin{array}{l}\text { Non-smoker } \\
\text { Passive smoker } \\
\text { Ex-smoker } \\
\text { Smoker }\end{array}$ & $\begin{array}{r}-1.56 \\
-1.43 \\
-0.39 \\
0.92\end{array}$ & 0.34 & $\begin{array}{r}-1.48 \\
-0.92 \\
-0.65 \\
0.80\end{array}$ & 0.29 \\
\hline $\begin{array}{c}\text { Dwelling } \\
\text { type }\end{array}$ & $\begin{array}{l}\text { Houses } \\
\text { Low-medium- } \\
\text { rise flats } \\
\text { High-rise flats }\end{array}$ & $\begin{array}{r}-0.31 \\
-0.00 \\
1.44\end{array}$ & . & $\begin{array}{r}-0.10 \\
-0.03 \\
0.54\end{array}$ & 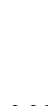 \\
\hline $\begin{array}{l}\text { Housing } \\
\text { area }\end{array}$ & $\begin{array}{l}\text { Bad } \\
\text { Good }\end{array}$ & $\begin{array}{r}0.68 \\
-0.43\end{array}$ & $0 \cdot 17$ & $\begin{array}{r}0.52 \\
-0.34\end{array}$ & 0.06 \\
\hline $\begin{array}{l}\text { Worked in } \\
\text { unhealthy } \\
\text { environ- } \\
\text { ment }\end{array}$ & $\begin{array}{l}\text { No } \\
\text { Yes }\end{array}$ & $\begin{array}{r}-0.58 \\
1.09\end{array}$ & $0 \cdot 17$ & $\begin{array}{r}-0.46 \\
0.86\end{array}$ & 0.20 \\
\hline
\end{tabular}

$R^{2}=0 \cdot 208$

\section{Conclusion}

Several factors have been associated with disorders of the respiratory system. The deleterious effect of smoking is now well established, ${ }^{14-16}$ and is supported by these results. Smoking is related to respiratory conditions more than is any other factor included in the model. Those who currently smoke cigarettes are found to have the most symptoms of respiratory disorders, followed by ex-smokers and then passive smokers. The most healthy respondents, in this sense, are those who have never smoked and who live in non-smoking households.

Given the significant effect of smoking, and the prevalence of respiratory conditions in the population, it is disturbing to note that the Health Education Council's anti-smoking campaign appears to have been only a partial success. As many as 201 respondents $(31 \%$ of the sample) said either that smoking did not affect health or that it depended on the amount smoked. Among smokers, 126 respondents $(38 \%$ of all smokers in the sample) expressed this opinion.

Industrial environments tend to have a high prevalence of chest disorders. ${ }^{1417}$ This especially affects those whose employment is located in unhealthy environments. ${ }^{16} \mathrm{~A}$ simple nominal variable obtained by asking respondents whether they had worked in an environment which they thought was bad for their health, accounts for a significant amount of the variance in respiratory conditions.

The main purpose of the survey was to examine a hypothesis that poor health is related to poor housing. When age, household class, smoking, work experience, and housing type are held constant, people who live in areas in which poor housing $\&$ predominates admit to more respiratory symptoms than those who live in "good" areas. Respiratory problems are associated with flats rather than houses, and with older accommodation. Although houses are the most healthy form of dwelling, this does not apply to between war housing estates where there is a high

rate of respiratory symptoms.
The highest mean scores on the respirator condition scale are found on those estates that ar $\vec{\Phi} \vec{v}$ classified as "difficult-to-let". These are all differen in terms of housing type. The residents on these estates tend to identify their chest conditions wit 3 their housing circumstances. Forty-three per cent 0 禺 respondents in "bad" areas with at least one symptom associated their chest condition with thei $\overrightarrow{0}$ housing situation. In "good" areas, 10\% made thiફ co response.

The causes of poor health are many and include genetic factors, consumption habits, employment, class, poverty, and poor housing. These results support a multi-cause hypothesis although they indicate that the major causes of respiratory conditions are smoking and employment history. When these are taken into consideration, there still appears to be a relation between poor housing and the presence of respiratory symptoms. The actual housing conditions responsible for this effect, however, are not clear.

The relation between housing and health is extremely complex. Those in better housing may be suffering health consequences of living for some time in very much worse conditions. Local authority housing policies tend to give priority for transfers to the ill who are living in bad housing. Thus the tendency is for the ill to move from bad to good housing rather than in the opposite direction. This means that analysis by current housing may understate the effects of poor housing. Further research is required to explore the way in which housing, health employment, and patterns of consumption interact over time. 


\section{References}

${ }^{1}$ Wohl AS. Endangered lives: Public health in Victorian Britain. London: Dent, 1983.

${ }^{2}$ Benjamin B. Social and economic factors affecting mortality. The Hague: Mauter, 1965.

${ }^{3}$ Office of Population Censuses and Surveys. Social trends. London: HMSO, 1984.

${ }^{4}$ Department of Health and Social Security. Inequalities in health: $A$ report of a research working group. London: HMSO, 1980.

${ }^{5}$ Morgan M, Chinn S. ACORN group, social class, and child health. J Epidem Comm Hlth, 1983; 31: 196-203.

${ }^{6}$ Dunleavy P. The politics of mass housing in Britain 1945-1975. Oxford; Clarendon Press, 1981.

${ }^{7}$ Fanning DM. Families in flats. Br Med J, 1967; 4: 382-6.

${ }^{8}$ Cronbach LJ. Co-efficient alpha and the internal structure of tests. Psychometrika, 1959; 16: 297-334.

${ }^{9}$ Zeller RA, Carmines EG. Measurement in the social sciences. Cambridge: Cambridge University Press, 1980.

${ }^{10}$ Guildford JP. Fundamental statistics in psychology and education, 4th ed. New York: McGraw-Hill, 1965.
"Department of Health and Social Security. Inequalities in health: $A$ report of a research working group. London: HMSO.

12 Verbrugge LM. Multiple roles and physical health of women and men. J Health Soc Behav, 1983; 24: 16-30.

${ }^{13}$ Scheussler K. Analysing social data: $A$ statistical orientation. Boston: Houghton.

${ }^{14}$ Lambert PM, Reid DD. Smoking, air pollution and bronchitis in Britain. Lancet, 1970; i: 853-7.

${ }^{15}$ Hawthorne VM, Fry JS. Smoking and health: The association between smoking behaviour, total mortality and cardio-respiratory disease in West Central Scotland. J. Epidemiol Community Health, 1978; 32: 260-6.

${ }^{16}$ Dean G, Lee PN, Todd GF, Wicken AJ, Sparks DN. Factors related to respiratory and cardio-vascular symptoms in the United Kingdom. J Epidemiol Community Health, 1978; 32: 260-6.

${ }^{17}$ Girt JL. Simple chronic bronchitis and urban ecological structure. In: McGlashan (ed), Medical Geography, London: Methuen, 1972.

${ }^{18}$ Gibson I. Class, health and profit. Norwich: University of East Anglia, 1981. 